\title{
INDICATIONS OF THE PATTERN OF OCULAR DISEASES IN THE ADEN PROTECTORATES*
}

\author{
BY \\ M. G. LYALL $\dagger$ \\ Aberdeen
}

THE Aden Protectorates, Eastern and Western, are situated in South-West Arabia, and include the islands of Kamaran and Socotra. They cover an area of about 112,000 square miles, being somewhat larger than the British Isles. For the most part the terrain is sand and rock, though in the northern part of the Western Protectorate, near the Yemen border, high mountains are found where rainfall sustains plant life. Elsewhere the climate is predominantly hot and dry. Water, however, is fairly plentiful in the Abyan and Lahez cotton-growing areas where mountain rains from the hinterland flood down through the wadis. The inhabitants are of mixed Semitic and Negroid stock in the West, with a further admixture of Javanese and FarEastern blood in the East. No census has been taken, but estimates of the total population are usually given as about 800,000 , or roughly the number of people living in Birmingham.

The Health Services in the territory are not yet fully developed and it had not been possible to treat most of the indigenous eye diseases effectively or at all when the information in this report was acquired. Where environmental factors are important in the aetiology of ocular disease it would appear valid to relate them to the incidence of these diseases in this area.

The ocular pathology that was frequently encountered differed from that seen in Europe in that the diseases, being untreated, had often run the full gamut of complications. Thus anterior staphyloma was common and was believed to be due to past perforation of a corneal ulcer (Wolff 1951a). Phthisis bulbi was also common, and it was supposed that corneal ulcer perforation had led to suppurative iridocyclitis and panophthalmitis and thence to phthisis bulbi (Wolff, 1951b). There was also a case of longstanding dacryocystitis which had led to much bone formation in the area of the lacrimal fossa. An associated phthisis bulbi may have been secondary to corneal ulceration following from the dacryocystitis, but was more probably due to past smallpox (Lyle and Cross, 1954).

As a first step in attempting more effectively to combat the indigenous eye diseases, a statistical survey of the ocular diseases of the population as a whole would have been desirable. This could not be carried out because of the lack of co-operation on the part of the populace, which observes purdah. It was, however, possible to carry out a trachoma survey of school-children, and also to analyse the case notes of patients presenting for treatment. 


\section{Trachoma Survey of SchoOl-ChILDREN}

The method used was the external examination of all the children at the school being visited by the naked eye, with eversion of the lids, supplemented by an ordinary binocular loupe where necessary (Figure). The diagnosis of the stages of trachoma was made according to the recommendations of the Expert Committee on Trachoma of the World Health Organisation (1956). Conjunctival smears for inclusion bodies were not taken in cases which might have been Stage I Trachoma. This condition was diagnosed only when there was conjunctival injection together with upper epithelial keratitis and pannus but no follicles or scarring. The original infection usually occurs long before school-age: before 2 years of age in Australia (Mann, 1960). Also it is passed through fairly quickly. Consequently the chances of meeting it during a survey of children of school-age were felt to be slim, and it was thought that not taking conjunctival smears would not compromise the results of the survey from a statistical point of view.

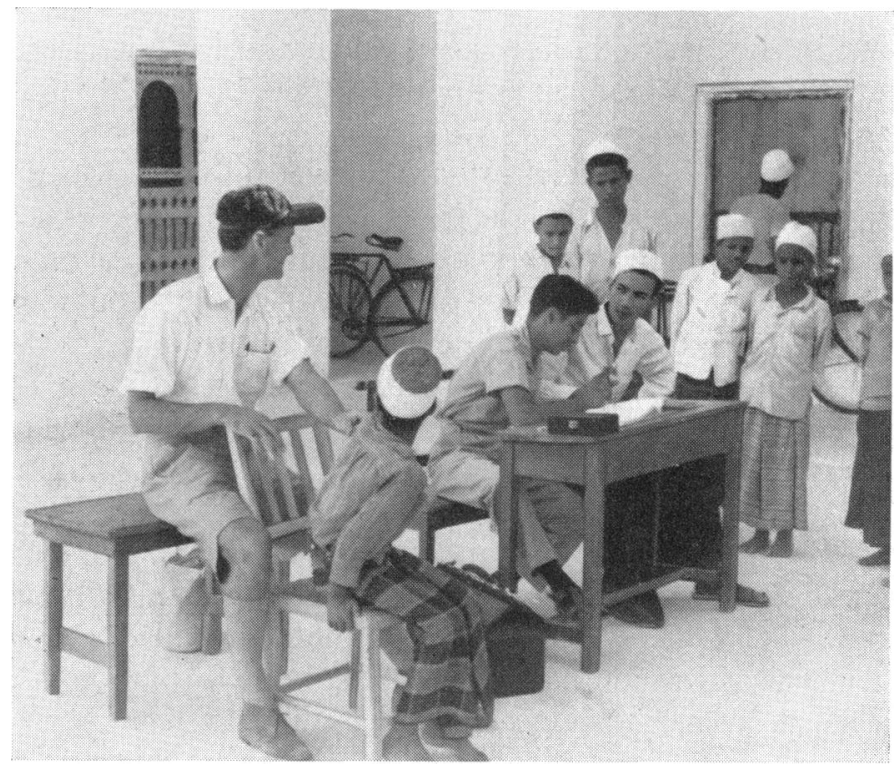

FIGURE.-School Trachoma Survey. The children's names are taken by the first clerk, while the second records the examination findings.

2,850 children from five areas were examined. These are Beihan, the Wadi Hadhramaut, Mukalla, Kamaran, and Abyan. Beithan lies beside an extension of the Empty Quarter or Great Sandy Desert. There is very little water there, less than in any of the other four areas in the survey. Most of the children's faces were dirty, with sand and dried tears crusted round the lids. They washed seldom. Sanitation was very primitive, the 
night soil being collected at irregular intervals from accumulations outside the houses. The average trachoma incidence among the school-children was the highest seen in the territory ( 99 per cent.), and the percentage of Stage IV (healed) cases was the lowest ( 7 per cent.).

The Wadi Hadhramaut showed the next highest incidence of the disease. Water was more plentiful than in Beihan, except in Shibam, and here there was a higher incidence of trachoma in the school-children ( 90 per cent.) than in the other centres (Tarim 76 per cent. and Saiun 62 per cent.). Shibam is an ancient city, built on the ruins of earlier habitations, so that it is raised above the level of the adjacent terrain. The wells for the city lie almost entirely in the wadi outside the city gates, so that the women have an exhausting journey home after drawing water. This means that water is scarce within the town and few children appeared to wash regularly.

In Saiun and Tarim the wells are distributed within the towns, and water is more readily available in the house. In a few houses there is piped water, and the Jabia, a large plunge-bath, is found in several, motor pumps being used. Sanitation is similar to that in Beihan, and as in Beihan flies occur in hordes everywhere, and may sometimes be seen clustered round the infants' eyelids. Kohol, a substance like mascara, is used frequently by all members of the community, one container supplying many.

The figures for Tarim are somewhat misleading because they include 42 Hadhrami boys who had just returned from Java because of political changes, and none of these boys had trachoma. They were the sons or grandsons of Hadhramis who had emigrated to Java in years past, and were of the same mixed stock as their cousins in Tarim. This demonstrates the over-riding importance of early environment in the epidemiology of the disease.

Mukalla lies between barren rocky hills and the sea. When the survey was made the fresh water supply was very low and had been estimated at 2 pints per head per day for the mass of the population. Sanitation was very bad, though improvements were being made. Much washing, both of clothes and of the person, was done in the adjacent sea. The incidence of trachoma in the school-children was less (46 per cent.) than in the interior.

On the island of Kamaran the situation was similar to that in Mukalla, with a poor fresh water supply, much of it distilled, and the sea close at hand. The incidence of trachoma in the school-children was 55 per cent.

Abyan is a cotton-growing area where well-water is fairly plentiful. In Giar, one of the two main towns, many of the houses have a piped supply. Sanitation is more advanced and the villages are cleaner. For the most part the school-children appeared to wash regularly, and the incidence of trachoma among them was the lowest seen in the territory (33 per cent.), much of this (16 per cent. of all children examined, or almost half the trachoma found) being in Stage IV (healed).

In this district, where there is considerable irrigation, fresh food-stuffs are 
much more plentiful than in the other areas considered so far. Nutrition is important in the aetiology of trachoma (D'Ermo, 1959), although its importance does not appear to be over-riding. Among some rich families in the interior, who could even afford to have food-stuffs flown in from Singapore, there was as much trachoma as in the poor Beduin of the same district.

The last community to be considered is the oil community in the town of Little Aden. The unskilled workers there were recruited for the most part from amongst up-country tribes at the inception of the refinery about 8 years ago. The writer did not have the opportunity of examining the children of these workers, but was informed by the Physician to the Company that no case of trachoma had been seen amongst them. These children live in houses which have piped water and water-borne sanitation. Street cleaning is well organized, and refuse is not found scattered everywhere, so that flies do not breed in large numbers. In addition the people are better fed than in the first four areas considered.

Table I (opposite) shows the results of the trachoma survey.

Factors important in the spread and severity of trachoma are usually given as unsatisfactory hygiene, overcrowding, and poverty (Radovanovic, 1960; Calvo-Flores 1960; Maythar and Feitelberg, 1960). At the Trachoma Conference convened by the World Health Organization in Tunis in 1959, the delegates agreed that "flies played an important part in associated ocular infections and possibly trachoma, and that an adequate and easily accessible water supply was necessary to effective control". The author was particularly impressed by the relationship between the availability of water and the incidence of trachoma in school-children in this territory.

Water appeared to be the most important factor in the epidemiology of the disease because without it washing could not take place, the children's faces were dirty, water-flushed sanitation was impossible, flies bred profusely, and fresh food-stuffs could not be grown. Where the water-supply had been increased, for example in Abyan or Little Aden, the incidence of the disease in school-children was either very low or zero. It was believed that the incidence of trachoma in school-children mirrored that in the general population, as the incidence of other endemic diseases is reflected in their incidence in school-children (Corkhill, 1959).

A mass campaign was started in which all school-children in the territory were treated for trachoma with topical Aureomycin in interrupted dosage over 6 months (Reinhards, Weber, and Maxwell-Lyons, 1959). Cases presenting at hospital had a 2 weeks' course of systemic sulphapyridazine (Mann, 1960). These measures were thought to be the best short-term policy. Long-term preventive measures, in particular the provision of a piped water-supply and water-borne sanitation where underground water supplies would allow it, were felt to offer a much better prospect of reducing the incidence of the disease, not only in the school-children but in the community as a whole. 
TABLE I

FINDINGS IN SCHOOL TRACHOMA SURVEY

\begin{tabular}{|c|c|c|c|c|c|c|c|c|c|}
\hline \multirow{3}{*}{\multicolumn{2}{|c|}{ Locality and Category of School }} & \multirow{3}{*}{$\begin{array}{l}\text { No. Ex- } \\
\text { amined }\end{array}$} & \multicolumn{5}{|c|}{ Stages (per cent.) } & \multirow{3}{*}{$\begin{array}{c}\text { Area } \\
\text { Average } \\
\text { (per cent.) }\end{array}$} & \multirow{3}{*}{$\begin{array}{l}\text { Other } \\
\text { Ocular } \\
\text { Diseases } \\
\text { (per cent.) }\end{array}$} \\
\hline & & & \multicolumn{5}{|c|}{ Stages of Trachoma } & & \\
\hline & & & $\mathbf{I}$ & II & III & $\underset{\text { IV }}{\text { Healed }}$ & $\underset{\text { Stages }}{\text { All }}$ & & \\
\hline \multirow{4}{*}{$\begin{array}{l}\text { Western Aden } \\
\text { Protectorate }\end{array}$} & $\begin{array}{l}\text { Abyan Area } \\
\text { Jaar (Male Primary) } \\
\text { Rowa (Male Primary) } \\
\text { Husn (Male Primary) } \\
\text { Bateis (Male Primary) } \\
\text { Zingibar (Male Primary) }\end{array}$ & $\begin{array}{r}235 \\
49 \\
96 \\
56 \\
160\end{array}$ & \multirow[t]{2}{*}{$\begin{array}{l}- \\
\bar{z}\end{array}$} & \multirow[t]{2}{*}{$\begin{array}{r}5 \\
14 \\
10 \\
32 \\
2\end{array}$} & \multirow[t]{2}{*}{$\frac{\frac{4}{2}}{21}$} & \multirow[t]{2}{*}{$\begin{array}{r}20 \\
12 \\
15 \\
20 \\
9\end{array}$} & \multirow[t]{2}{*}{$\left.\begin{array}{l}30 \\
28 \\
27 \\
52 \\
33\end{array}\right\}$} & \multirow[t]{2}{*}{33} & \multirow[t]{2}{*}{$\begin{array}{l}3 \\
4 \\
6 \\
4 \\
4\end{array}$} \\
\hline & Total & 586 & & & & & & & \\
\hline & $\begin{array}{l}\text { Beihan Area } \\
\text { Ulya (Male Primary } \\
\text { Nuqub (Male Primary } \\
\text { Harega (Male Primary) }\end{array}$ & $\begin{array}{l}43 \\
29 \\
25\end{array}$ & $\frac{1}{-}$ & $\begin{array}{l}9 \\
7 \\
8\end{array}$ & $\begin{array}{l}84 \\
93 \\
88\end{array}$ & $\frac{7}{-}$ & $\left.\begin{array}{r}100 \\
100 \\
96\end{array}\right\}$ & 99 & $\frac{7}{12}$ \\
\hline & Total & 97 & & & & & & & \\
\hline \multirow{4}{*}{$\begin{array}{l}\text { Eastern Aden } \\
\text { Protectorate }\end{array}$} & $\begin{array}{l}\text { Mukulla } \\
\text { West (Male Primary) } \\
\text { Belad (Male Primary) } \\
\text { Gariya (Male Primary) } \\
\text { Intermediate (Male Primary) } \\
\text { Intermediate Naga (Male Primary) } \\
\text { H.B.L. (Female Primary) } \\
\text { M.R.A. (Female Primary) }\end{array}$ & $\begin{array}{r}288 \\
209 \\
98 \\
203 \\
203 \\
32 \\
13\end{array}$ & \multirow[t]{2}{*}{$\begin{array}{l}\bar{z} \\
\bar{z} \\
=\end{array}$} & \multirow[t]{2}{*}{$\begin{array}{r}8 \\
6 \\
11 \\
5 \\
7 \\
9 \\
8\end{array}$} & \multirow[t]{2}{*}{$\begin{array}{r}27 \\
21 \\
26 \\
30 \\
28 \\
9 \\
16\end{array}$} & \multirow[t]{2}{*}{$\begin{array}{l}15 \\
14 \\
16 \\
23 \\
17 \\
47 \\
\end{array}$} & \multirow[t]{2}{*}{$\left.\begin{array}{l}50 \\
41 \\
53 \\
58 \\
52 \\
65 \\
24\end{array}\right\}$} & \multirow[t]{2}{*}{46} & \multirow[t]{2}{*}{$\begin{array}{l}3 \\
6 \\
3 \\
6 \\
2 \\
3 \\
3\end{array}$} \\
\hline & \multicolumn{2}{|l|}{ Total } & & & & & & & \\
\hline & $\begin{array}{l}\text { Wodi } \\
\text { Hadhramaut } \\
\text { Shibam (Male Primary) } \\
\text { Tarim (Male Intermediate) } \\
\text { Saiun (Male Primary) } \\
\text { Saiun (Female Primary) }\end{array}$ & $\begin{array}{r}190 \\
345 \\
230 \\
57\end{array}$ & \multirow[t]{2}{*}{ E } & \multirow[t]{2}{*}{$\begin{array}{r}26 \\
9 \\
15 \\
26\end{array}$} & \multirow[t]{2}{*}{$\begin{array}{l}49 \\
57 \\
41 \\
30\end{array}$} & \multirow[t]{2}{*}{$\begin{array}{r}15 \\
10 \\
8 \\
-\end{array}$} & \multirow[t]{2}{*}{$\left.\begin{array}{l}90 \\
76 \\
64 \\
56\end{array}\right\}$} & \multirow[t]{2}{*}{65} & \multirow[t]{2}{*}{$\begin{array}{l}\mathbf{5} \\
\mathbf{4} \\
\mathbf{3} \\
\mathbf{4}\end{array}$} \\
\hline & Total & 1032 & & & & & & & \\
\hline Islands & Kamaran (Male Primary) & 54 & - & 32 & 4 & 10 & 55 & 55 & 6 \\
\hline
\end{tabular}

The incidence of trachoma in school-children in the territory was similar to that found in the inhabitants of similar lands elsewhere. Thus, in Morocco an incidence of 50 to 100 per cent. is reported (Malo, 1959). In Jordan an incidence of 80 per cent. of Stage IV trachoma was found in people under 25 years of age (Gilkes, 1958). In the neighbouring country of Saudi Arabia most people in a group of over 5,000 had clinical trachoma (Bell, McComb, Murray, Chang, Shih-Man, and Snyder, 1959; Feng, Chang, Shih-Man, Smith, and Snyder, 1959).

Of the other diseases seen in external examination of the school-children, the chief were squint, leucoma (much of it adherent), anterior staphyloma, phthisis bulbi, and Bitot's spots indicating avitaminosis A.

\section{Analysis of 555 Consecutive Cases of Ocular Disease presenting at Hospital (MAKHZAN, ABYAN).}

Table II (overleaf) shows the results of this analysis. The conditions as shown incidental are considered to have no aetiological relationship to those shown as presenting. 
It is interesting that 151 ( 37 per cent.) of these cases showed signs of active or healed trachoma while presenting with another condition unrelated to it aetiologically. This figure gives an indication of the incidence of trachoma

\section{TABLE II}

ANALYSIS OF 555 CONSECUTIVE CASES OF OCULAR DISEASE

Conditions tabulated as incidental are considered to have no aetiological relationship to those shown as presenting.

\begin{tabular}{|c|c|c|c|c|c|c|}
\hline \multicolumn{5}{|c|}{ Condition } & Presenting & Incidental \\
\hline \multirow{3}{*}{ Conjunctiva } & Trachome & \multicolumn{3}{|c|}{\begin{tabular}{|l} 
I \\
II \\
III \\
IV \\
V Entropion and Trichiasis
\end{tabular}} & $\begin{array}{r}2 \\
36 \\
36 \\
18\end{array}$ & $\begin{array}{r}- \\
2 \\
34 \\
115 \\
4\end{array}$ \\
\hline & \multicolumn{2}{|c|}{ Conjunctivitis } & \multicolumn{2}{|c|}{$\begin{array}{l}\text { Undifferentiated } \\
\text { Phlyctenular }\end{array}$} & $\begin{array}{r}38 \\
4\end{array}$ & 二 \\
\hline & \multicolumn{4}{|c|}{$\begin{array}{l}\text { Pinguecula } \\
\text { Melanoma of limbus }\end{array}$} & $\begin{array}{r}10 \\
1\end{array}$ & -1 \\
\hline \multirow{5}{*}{ Cornea } & Keratitis & \multicolumn{3}{|c|}{$\begin{array}{l}\text { Undifferentiated } \\
\text { Superficial punctate } \\
\text { Bullous }\end{array}$} & $\begin{array}{r}7 \\
4 \\
11\end{array}$ & $\overline{-}$ \\
\hline & \multicolumn{4}{|c|}{ Anterior staphyloma } & 6 & - \\
\hline & Ulcer & \multicolumn{3}{|c|}{$\begin{array}{l}\text { Undifferentiated } \\
\text { Neuroparalytic } \\
\text { Serpiginous }\end{array}$} & $\begin{array}{r}15 \\
1 \\
1\end{array}$ & $\frac{2}{-}$ \\
\hline & \multicolumn{4}{|c|}{$\begin{array}{l}\text { Pterygium } \\
\text { Foreign body } \\
\text { Chemical burn } \\
\text { Band-shaped degeneration } \\
\text { Abrasion }\end{array}$} & $\begin{array}{r}21 \\
24 \\
2 \\
4 \\
2\end{array}$ & $\frac{29}{-}$ \\
\hline & Leucoma & \multicolumn{3}{|c|}{$\begin{array}{l}\text { Simple } \\
\text { Adherent }\end{array}$} & $\begin{array}{l}19 \\
25\end{array}$ & $\begin{array}{l}1 \\
1\end{array}$ \\
\hline Sclera & \multicolumn{4}{|c|}{ Episcleritis } & 1 & 1 \\
\hline Uveal Tract & \multicolumn{4}{|c|}{$\begin{array}{l}\text { Anterior uveitis } \\
\text { Posterior uveitis } \\
\text { Anterior and posterior uveitis }\end{array}$} & $\begin{array}{l}4 \\
6 \\
6\end{array}$ & - \\
\hline \multirow{4}{*}{ Retina } & \multicolumn{2}{|c|}{ Retinopathy } & \multicolumn{2}{|c|}{$\begin{array}{l}\text { Undifferentiated } \\
\text { Hypertensive }\end{array}$} & $\overline{2}$ & $\begin{array}{l}1 \\
1\end{array}$ \\
\hline & \multicolumn{4}{|c|}{ Retinitis pigmentosa } & 1 & 1 \\
\hline & \multicolumn{3}{|c|}{ Macular degeneration } & $\begin{array}{l}\text { Senile } \\
\text { Hereditary }\end{array}$ & $\begin{array}{l}1 \\
1\end{array}$ & 二 \\
\hline & \multicolumn{4}{|c|}{$\begin{array}{l}\text { Non-myelinated nerve fibres } \\
\text { Colloid bodies } \\
\text { Angiospasm }\end{array}$} & $\overline{-}$ & $\begin{array}{r}1 \\
1 \\
1\end{array}$ \\
\hline Optic Nerve & \multicolumn{4}{|c|}{$\begin{array}{l}\text { Primary optic atrophy } \\
\text { Optic neuritis }\end{array}$} & $\begin{array}{l}5 \\
2\end{array}$ & - \\
\hline
\end{tabular}




\begin{tabular}{|c|c|c|c|c|}
\hline \multicolumn{3}{|c|}{ Condition } & \multirow{2}{*}{$\begin{array}{c}\text { Presenting } \\
50 \\
9 \\
3 \\
3\end{array}$} & \multirow{2}{*}{$\begin{array}{c}\text { Incidental } \\
-\frac{14}{3} \\
1\end{array}$} \\
\hline Lens & Cataract & $\begin{array}{l}\text { Senile } \\
\text { Senile and dislocated } \\
\text { Traumatic } \\
\text { Congenital }\end{array}$ & & \\
\hline Glaucoma & \multicolumn{2}{|c|}{$\begin{array}{l}\text { Chronic, simple } \\
\text { Acute congestive } \\
\text { Absolute_-* }\end{array}$} & $\begin{array}{r}16 \\
3 \\
9\end{array}$ & - \\
\hline Lids & \multicolumn{2}{|c|}{$\begin{array}{l}\text { Blepharitis } \\
\text { Chalazion } \\
\text { Symblepharon } \\
\text { Hordeolum and lid abscess } \\
\text { Epithelioma }\end{array}$} & $\begin{array}{r}7 \\
7 \\
1 \\
16 \\
1\end{array}$ & $\begin{array}{l}- \\
1 \\
-\end{array}$ \\
\hline Lacrimal Apparatus & \multicolumn{2}{|c|}{ Dacryocystitis } & 7 & 1 \\
\hline Orbit & \multicolumn{2}{|c|}{ Orbital tumour } & 2 & - \\
\hline Movements & \multicolumn{2}{|c|}{$\begin{array}{l}\text { Squint } \\
\text { Nystagmus } \\
\text { Convergence deficiency }\end{array}$} & $\begin{array}{r}-1 \\
1\end{array}$ & - \\
\hline Avitaminosis & \multicolumn{2}{|c|}{ Avitaminosis A } & 9 & 2 \\
\hline Miscellaneous & \multicolumn{2}{|c|}{$\begin{array}{l}\text { Refractive errors } \\
\text { Panophthalmitis } \\
\text { Penetrating injuries } \\
\text { Trifling ocular condition or None (e.g. sub- } \\
\quad \text { tarsal foreign body) }\end{array}$} & $\begin{array}{r}59 \\
2 \\
12 \\
67\end{array}$ & $\frac{12}{-}$ \\
\hline \multicolumn{3}{|l|}{ Totals } & 555 & 238 \\
\hline
\end{tabular}

* Much of this was due to dislocated cataract.

amongst the local population, and agrees well with that found in schoolchildren in the same area (35 per cent.).

31 patients presented with pinguecula or its related condition pterygium (Fuchs, 1891, 1892) and an almost equal number (29, 5 per cent.) showed pterygium as an incidental finding. This is in keeping with the high incidence of the disease in similar sunny climates, for example Australia (TrevorRoper, 1955).

Bullous keratitis is found fairly commonly in the territory, and twelve cases were seen in the series, all of them in old people. It occurred in eyes that were not blind and did not show signs of long-standing uveitis or glaucoma, features which lead to the condition according to Fuchs (1881). The lower half or third of the cornea was affected. The cause of the condition is not known. It was treated empirically with topical atropine and corticoids together with the administration of vitamins A, D, and C. In some cases, where the patients had persisted with treatment for several weeks, repeated slit-lamp examination showed a gradual bursting of the bullae and their replacement by scar tissue, the cornea becoming flattened. 
Couching by itinerant quacks is still common in the territory. Nine cases in the series presented with uncomplicated dislocated cataract, and there were nine cases classed as absolute glaucoma, nearly all of them secondary to lens dislocation. Some of these cases showed dislocation of the nucleus only, with most of the capsule left in the pupillary area. In one case the lens nucleus lay in the anterior chamber.

Hypertensive retinopathy was seen very rarely in the territory, and in the whole series there are only two cases, though ophthalmoscopy was not performed in all. The spare diet with its low fat content, consisting as it does of rice, lean meat, and vegetables, may be of importance in the rarity of hypertension in the territory.

It had been possible to treat only a few diabetics in the territory, so that the absence of diabetic retinopathy is readily explained. No patient in the group presented with squint, as this is usually regarded as an individual characteristic rather than a disease. Onchocerciasis occurs in the territory, particularly in the hills near the Yeman border (Fawdry, 1957), but it usually affects only the legs, though sometimes the trunk is also involved. Although it was carefully looked for, no ocular case was seen.

\section{Summary}

(1) The results are given of a trachoma survey of 2,850 school-children in the Aden Protectorates, and a relationship is indicated between the incidence of trachoma in the various areas and the availability of water.

(2) An analysis is given of 555 consecutive cases of eye disease presenting at Makhzan Hospital, Abyan.

Many thanks are due to Mr. C. Cockburn, F.R.C.S., for his encouragement, and to Miss Philip for her considerable secretarial assistance.

\section{REFERENCES}

Bell, S. D., McComb, D. E., Murray, E. S., Chang, R., Shih-Man, and Snyder, J. C. (1959). Amer. J. trop. Med. Hyg., 8, 492.

Calvo-Flores, F. M. (1960). Arch. Soc. oftal. hisp.-amer., $20,347$.

CoRkHiLl, N. L. (1959). "Annual Report on the Protectorate Health Service for 1958". 18, 127, 129. Aden Government Printer.

D'ERMo, F. (1959). Rass. Med. Sarda., 61, 537.

Feng, M., Chang, R., Shim-Man, Smith, T. R., and Snyder, J. C. (1959). Amer. J. trop. Med. Hyg., 8, 501.

FAWDRY, A. L. (1957). Trans. roy. Soc. trop. Med. Hyg., 51, 253.

FuCHS, E. (1881). v. Graefes Arch. Ophthal., 27, pt. 3, p. 66.

(1891). Ibid., 37, pt. 3, p. 143. (1892). Ibid., 38, pt. 2, p. 1 .

GILKES, M. (1958). Trans. ophthal. Soc. U.K., 78, 227.

LYLE, T. KEITH, and Cross, A. G. (1954). "May and Worth's Manual of Diseases of the Eye", 11 th ed., p. 188. Baillière, Tindall, and Cox, London.

MaLo, C. (1959). Rev. int. Trachome, 36, 359.

MaNN, I. (1960). Brit. J. Ophthal., 44, 32.

MAYTHAR, B., and FeitelberG, I. (1960). Harefuah (Hebrew ed.), 59, 167.

Radovanovic, M. (1960). Proc. All-India ophthal. Soc. 1957, 17, 164.

ReInHaRdS, J., Weber, A., and MAXWell-LyONS, F. (1959). Bull. Wld Hith Org., $21,665$.

TREVOR-Roper, P. D. (1955). "Ophthalmology", p. 434. Lloyd-Luke, London.

WolfF, E. (1951a). "A Pathology of the Eye", 3rd ed., p. 6. Lewis, London. (1951b). Ibid., p. 83. 